\title{
Gambaran Penggunaan Herbal Pelancar ASI (Galactagogues) di Desa Wonosari Kabupaten Pringsewu
}

\author{
Eka Tri Wulandari ${ }^{1}$, Psiari Kusuma Wardani ${ }^{2}$ \\ ${ }^{1,2}$ Akademi Kebidanan Medica Bakti Nusantara Pringsewu Lampung \\ Email: fatihnyaumi@gmail.com
}

\section{ARTICLE INFO}

Keyword:

Breastmilk

Galaktogogue

ASI

Daun Kelor

Herbal

\section{*) corresponding author}

Dosen Akademi Kebidanan Medica Bakti Nusantara Pringsewu Lampung

\begin{abstract}
A B STRACT
Back to nature lifestyle has became a trend recently so that the community returned to use various natural materials, including treatment with medicinal plants (herbs). Actually, since ancient times Indonesian people have known and used medicinal plants as an effort to overcome various health problems, long before formal health services with modern medicines reached the community. The aim of this research is to know the descriptions of Herbs co nsumed by breastfeeding mothers in Wonosari, Gadingrejo, Pringsewu in 2019. This research was conducted in Wonosari, Gadingrejo, Pringsewu in 2019. This type of the research is a descriptive study with analytical survey methods. The research subjects were nursing mothers with a population of 120 respondents and the research sample used a total sampling technique, with a total of 120 respondents. The data collection is primary data, namely the data obtained directly by using the checklist. The results of this research show that most of the respondents consumed katuk leaves (Sauropus androgynus) to increase milk production as many as 52 respondents (43.4 percent), then the consumption of Moringa leaves was 38 respondents (31.6 percent), consumption of turmeric and tamarind was 9 respondents (7,5 percent),consumption of Turi leaves (Sesbania grandiflora) was 3 respondents (2,5 percent),consumption of roasted corn 4 respondents (3.3 percent),consumption of spinach was 4 respondents $(4.2$ percent) and long bean leaves was 9 respondents ( 7.5 percent), while the papaya fruit, banana flowers, and green bean extract were not consumed by respondents to increase breastmilk production. The researcher suggests nursing mothers tobenefit plants and food around them which can increase breastmilk production. For other researchers, they can do further research with different variables so that it is known which galactogogue materials are the most effective in increasing breastmilk production.
\end{abstract}




\section{PENDAHULUAN}

Gaya hidup kembali ke alam (back to nature) menjadi tren saat ini sehingga masyarakat kembali memanfaatkan berbagai bahan alam,termasuk pengobatan dengan tumbuhan obat (herbal). Sejak zaman dahulu masyarakat Indonesia mengenal dan menggunakan tanaman berkhasiat obat sebagai salah satu upaya menanggulangi berbagai masalah kesehatan, jauh sebelum pelayanan kesehatan formal dengan obat-obatan modern menyentuh masyarakat. Selain lebih ekonomis, efek samping ramuan herbal sangat kecil dan penggunaan obat herbal alami dengan formulasi yang tepat sangat penting dan tentunya lebih aman dan efektif (Hidayati, 2016)

Angka kematian bayi di indonesia berdasarkan Hasil Survey Demografi dan Kesehatan Indonesia (SDKI) tahun 2012 masih cukup inggi yaitu sebesar 32 kematian per 1.000 kelahiran hidup (SDKI, 2012) dan bangsa indonesia harus mampu menurunkan angka kematian bayi hingga 23 per 1.000 kelahiran hidup pada tahun 2015 sesuai dengan Millenium Defellopmen Goals 4 (Bappenas 2011. Dalam lilis 2014).

Hasil SDKI 2012, cakupan ASI esklusif di indonesia baru mencapai 27,1\% angka ini masi rendah, karena arget cakupan pemberian ASI esklusif pada bayi kurang dari 6 bulan adalah 80\% (Riskesdes, 2012.Dalam lilis 2014).

Penyebab kurang lancarnya ASI kemungkinan karena faktor hormon atau makanan yang dikonsumsi, untuk memperlancar ASI salah satunya dapat dilakukan dengan mengkonsumsi obat tradisional. Obat tradisional dapat berasal dari sesuatu yang dijumpai di lingkungan sekitar kita. Salah satu jenis herbal yang terdapat di desa Babakan Loa untuk memperlancar produksi ASI, herbal ini terdiri atas: daun katuk, buah pepaya, sari kacang hijau, jantung pisang, ekstrak kelor, kunyit dan asam jawa.

Seiring dengan perkembangan zaman, terjadi peningkatan berkembangan Ilmu Pengetahuan dan Teknologi (IPTEK) yang menuntut adanya Sumber Daya Manusia (SDM) yang berkualitas dan mempunyai produktivitas yang tinggi hingga mampu meningkatkan kesejahteraan dan daya saing di era globalisasi. Untuk meningkatkan kualitas SDM, salah satu yaitu dengan pemberian Air Susu Ibu (ASI) secara eksklusif pada bayi merupakan cara terbaik bagi peningkatan kualitas SDM sejak dini yang akan menjadi penerus bangsa (Puspitasari, 2011)

Adanya faktor protektif dan nutrien yang sesuai dalam air susu ibu (ASI) menjamin status gizi bayi baik serta kesakitan dan kematian anak menurun. Beberapa penelitian epidemiologis menyatakan bahwa ASI melindungi bayi dan anak dari penyakit infeksi, misalnya diare, otitis media, dan infeksi saluran pernafasan akut bagian bawah. Kolostrum mengandung zat kekebalan 10-17 kali lebih banyak dari susu matang (matur). Zat kekebalan yang terdapat pada ASI antara lain akan melindungi bayi dari penyakit diare dan menurunkan kemungkinan bayi terkena penyakit infeksi telinga, batuk, pilek, danpenyakit alergi.

Cakupan pemberian ASI eksklusif secara nasional di Indonesia berfluktuasi selama 3 tahun terakhir, cakupan pemberian ASI eksklusif pada bayi 0-5 bulan turun dari 62,2\% tahun 2007 menjadi 56,2\% pada tahun 2008, namun meningkat lagi pada tahun 2009 menjadi 61,3\%. Sedangkan cakupan pemberian ASI eksklusif pada bayi sampai 6 bulan turun dari 28,6\% pada tahun 2007 menjadi 24,3\% pada tahun 2008 dan naik lagi menjadi 34,4\% pada tahun 2009 (Haris, 2011). Menyusui bayi di Indonesia sudah menjadi budaya namun praktik pemberian ASI masih jauh dari yang diharapkan. Menurut Survei Demografi Kesehatan Indonesia 2010 hanya 10\% bayi yang memperoleh ASI pada hari pertama, yang diberikan ASI kurang dari 2 bulan sebanyak 73\%, yang diberikan ASI 2 sampai 3 bulan sebanyak 53\% yang diberikan ASI 4 sampai 5 bulan sebanyak 20\% dan menyusui eksklusif sampai usia 6 bulan sebanyak 49\% (Pusdiknakes-WHO, 2010).

Dampak dari ibu yang tidak memberikan ASI kepada bayi dapat menyebabkan masalah kesehatan seperti kekurangan gizi, penurunan kekebalan tubuh, mudah terserang penyakit. Beberapa faktor penyebab tidak diberikannya ASI pada bayi seperti pengetahuan ibu yang kurang, 
pendidikan rendah, perilaku, budaya, pekerjaan, status kesehatan ibu. Salah satu factor penyebab tidak diberikannya ASI adalah status kesehatan ibu, dimana status kesehatan ibu dapat mempengaruhi jumlah ASI yang di produksi menjadi berkurang, hal ini dikarenakan kurangnya konsumsi gizi pada ibu menyusui.

Solusi yang dapat dilakukan agar ibu berhasil dalam memproduksi ASI, ada beberapa saran yang perlu diperhatikan para ibu yang sedang memberikan ASI pada bayi, yaitu mengkonsumsi sayur-sayuran dan buah-buahan yang dapat meningkatkan volume ASI. Hal ini sesuai dengan penelitian yang dilakukan peneliti terdahulu tentang konsumsi herbal yang dapat meningkatkan produksi ASI, dimana dalam herbal seperti sayuran dan buah mengandung banyak gizi yang dibutuhkan ibu untuk produksi ASI. Jumlah ASI sedikit bisa diatasi ibu dengan mengkonsumsi daun katuk, buah pepaya, jantung pisang, kacang, daun kelor, kunyit, dan asam jawa. Sayuran tersebut merupakan sayuran yang mudah didapat yang dimanfaatkan untuk meningkatkan produksi ASI. Alasan ini sesuai dengan penelitian yang telah dilakukan oleh Astawan. Menurutnya, selain karbohidrat, sayuran tersebut juga mengandung protein, mineral (fosfor, kalsium dan besi, serta sejumlah vitamin A, B1 dan C).

Berdasarkan pra survey yang dilakukan peneliti dengan wawancara pada $10 \mathrm{ibu}$ di Desa Wonosari terdapat $6(60 \%)$ ibu menyebutkan tidak lancarnya produksi ASI, dan ibu mengatakan kurangnya konsumsi makanan bergizi seperti sayuran dan buah-buahan. pada ibu menyusui, berdasarkan hasil penelitian terdahulu menyebutkan makanan dan buah-buahan seperti daun katuk, papaya, kunyit dan lainnya dapat memperlancar produksi ASI karena mengandung zat gizi seperti fosfor, besi, kalsium, vitamin, protein, minyak astiri yang dapat memperlancar produksi ASI. Berdasarkan hal tersebut maka peneliti mengambil judul "Gambaran herbal Untuk Memperlancar ASI di Desa Wonosari Kecamatan Gadingrejo Kabupaten Pringsewu tahun 2019”.

\section{METODE}

Dalam penelitian ini penulis menggunakan jenis penelitian kuantitatif, jenis penelitian ini merupakan jenis penelitian untuk mendapatkan gambaran yang akurat dari sebuah karakteristik masalah yang mengklasifikasikan suatu data dan pengambilan data yang berhubungan dengan angka-angka baik yang diperoleh dari hasil pengukuran maupun nilai suatu data yang diperoleh (Notoatmodjo, 2012). Penelitian ini dilaksanakan di Desa Wonosari Kecamatan Gadingrejo Kabupaten Pringsewu tahun 2019.

Populasi adalah keseluruhan obyek penelitian atau obyek yang diteliti (Notoatmodjo, 2012). Populasi dalam penelitian ini adalah semua ibu menyusui di Desa Wonosari Kecamatan Gadingrejo Kabupaten Pringsewu tahun 2019 sebanyak 120 orang.

Sampel dalam penelitian ini adalah bagian dari jumlah dan kaarakteristik yang di miliki oleh poplasi tersebut (Sugiyono, 2013). Penentuan sampel menggunakan tehnik total sampling yaitu dengan mengambil keseluruhan anggota populasi sesuai dengan konteks penelitian, sehingga sampel dalam penelitian ini adalah 120 ibu menyusui di Desa Wonosari Kecamatan Gadingrejo Kabupaten Pringsewu.

Data yang diperoleh dan kemudian di analisa dengan melakukan penyelesaiandata sesuai dengan kriteria yang ada. Dimaksud untuk mengetahui distribusi frekuensi dari sub variabel yang diamati sehingga dapat mengetahui gambaran dari variabel yang diteliti (Notoadmojo, 2010), baik variabel dependent maupun independen dengan menggunakan rumus:

$P=\frac{F}{N} \times 100 \quad \%$

Keterangan :

$\mathrm{P}$ : Prosentase

$\mathrm{F}$ : Frekuensi

$\mathrm{N}$ : Jumlah Responden

$100 \%$ : Konstanta
(Budiarto, 2010) 


\section{HASIL DAN PEMBAHASAN}

Tabel 1

Distribusi Frekuensi Galaktogogue yang dikonsumsi ibu menyusui (N=120)

\begin{tabular}{llcc}
\hline \multicolumn{1}{c}{ Galaktogogue } & Frekuensi & Persentase $(\%)$ \\
\hline 1. Daun Katuk & 52 & 43,4 \\
2. Buah Pepaya & 0 & 0,0 \\
3. Jantung Pisang & 0 & 0,0 \\
4. Sari Kacang Hijau & 0 & 0,0 \\
5. Daun kelor & 38 & 31,6 \\
6. Kunyit dan Asam & 9 & 7,5 \\
7. Klebet & 0 & 3,3 \\
8. Jitan & 0 & 4,2 \\
9. Dan lain-lain & & 7,5 \\
a. Sangrai Jagung & 4 & 2,5 \\
b. Bayam & 5 & \\
c. Daun Kacang Panjang & 9 & \\
d. Daun Turi & 3 & \\
\end{tabular}

Berdasarkan hasil penelitian dapat dikethaui bahwa sebagian besar responden mengkonsumsi daun katuk untuk meningkatkan produksi ASI yaitu sebanyak 52 responden $(43,1 \%)$, selanjutnya adalah konsumsi daun kelor yaitu sebanyak 38 responden $(31,6 \%)$, kunyit dan asam 9 responden (7.5\%), daun turi 3 responden $(2,5 \%)$, sangrai jagung 4 responden $(3,3 \%)$, bayam 5 responden $(4,2 \%)$ dan daun kacang panjang 9 responden $(7,5 \%)$, sedangkan buah pepaya, jantung pisang dan sari kacang hijau tidak dikonsumsi oleh responden untuk meningkatkan produksi ASI (tabel 1).

Berdasarkan hasil penelitian dapat dikethaui bahwa sebagian besar responden mengkonsumsi daun katuk untuk meningkatkan produksi ASI yaitu sebanyak 52 responden $(43,1 \%)$, selanjutnya adalah konsumsi daun kelor yaitu sebanyak 38 responden $(31,6 \%)$, kunyit dan asam 9 responden $(7.5 \%)$, daun turi 3 responden $(2,5 \%)$, sangrai jagung 4 responden $(3,3 \%)$, bayam 5 responden $(4,2 \%)$ dan daun kacang panjang 9 responden $(7,5 \%)$, sedangkan buah pepaya, jantung pisang dan sari kacang hijau tidak dikonsumsi oleh responden untuk meningkatkan produksi ASI.

Berdasarkan hasil penelitian dapat diketahui bahwa sebagian besar responden mengkonsumsi daun katuk untuk meningkatkan produksi ASI yaitu sebanyak 52 responden $(43,4 \%)$, selanjutnya adalah konsumsi daun kelor yaitu sebanyak 38 responden $(31.6 \%)$, kunyit dan asam 9 responden (7.5\%), daun turi 3 responden (2.5\%), sangrai jagung 4 responden $(3,3 \%)$, bayam 5 responden $(4,2 \%)$ dan daun kacang panjang 9 responden $(7,5 \%)$, sedangkan buah pepaya, jantung pisang dan sari kacang hijau tidak dikonsumsi oleh responden untuk meningkatkan produksi ASI.

Salah satu upaya memperbanyak ASI, adalah meningkatkan kualitas makanan yang berpengaruh secara langsung pada produksi air susu, misalnya sayur-sayuran hijau, daun katuk, daun ubi jalar, daun pepaya dan sebagainya. Daun katuk mengandung hampir $7 \%$ protein dan $19 \%$ serat kasar, vitamin K, pro-vitamin A (betakarotin), Vitamin B dan C. Mineral yang dikandung adalah Kalsium $(2,8 \%)$ zat besi, kalium, fosfor dan magnesium. Perlu diketahui bahwa daun katuk ini juga mengandung papaverina, yaitu suatu alkaloid yang juga terdapat pada candu (opium). Konsumsi yang berlebihan dapat menyebabkan efek samping seperti keracunan papaverina. Warna daun katuk yang hijau gelap menunjukkan kadar klorofil yang tinggi. Daun katuk mempunyai sifat yang khas yaitu manis, mendinginkan dan membersihkan darah, khasiat antipiretik dan laktagog.

Masyarakat di Desa Wonosari Kecamatan Gadingrejo Kabupaten Pringsewu, biasanya menanam tanaman katuk di sekitar pekarangan rumah, atau sebagai tanaman tumpang sari yang ada di sekitar kebun mereka, karena tanaman katuk tergolong tanaman yang mudah tumbuh, tidak memerlukan penanganan khusus dan tidak membutuhkan lahan yang luas. 
Sesuai dengan hasil penelitian ini bahwa upaya untuk meningkatkan produksi ASI dapat dilakukan dengan mengkonsumsi ibu sehari-hari terutama dengan menambah menu sayur daun katuk atau minum kapsul katuk sesuaidosis. Daun katuk sudah dikenal oleh nenek moyang kita sebagai sayur pelancar ASI. Aktifitas fisiologis eksrak daun katuk memiliki antioksidan pada tubuh manusia karena dapat menghambat radikal bebas hidroksil (Narumon Benjapak, dkk. 2008; dalam Andari Ana, 2010).

Ahli gizi Puskesmas Pakis, Sulasmi, SKM, M.Kes menjelaskan, sebenarnya khasiat dari daun katuk ini tidak hanya sebatas meningkatkan produksi ASI saja, namun juga ada ragam khasiat lain yang terkandung di daun yang berwarna hijau tua ini. Khasiat tersebut yakni menjaga kesehatan mata, mencegah anemia, osteoporosis, dan juga sembelit. Dalam 100 gram daun katuk, terkandung komposisi zat gizi seperti energi 58 kalori, protein 6,4 gram, lemak 1 gram, hidrat arang 9,9 gram, serat 1,5 gram, kalsium $233 \mathrm{Mg}$, fosfor $98 \mathrm{Mg}$, besi 3,5 Mg, karoten (vitamin A) $10020 \mathrm{Mcg}$, vitamin C $164 \mathrm{Mg}$, air 81 gram.

Agar kandungan nutrisi pada tanaman ini tidak hilang dan dapat memberikan manfaat yang maksimal bagi tubuh, maka cara pengolahannya pun harus benar-benar diperhatikan. Hal ini karena cara pengolahan yang salah justru dapat merusak kandungan gizi di dalamnya. Jika terlalu lama matang dalam memasak dengan bahan daun katuk, dapat menurunkan kualitasnya sebagai pelancar ASI. Untuk memasaknya, hanya dibutuhkan waktu 3 menit saja sejak air mendidih.

Berdasarkan pengamatan peneliti, kebiasaan ibu di Desa Wonosari Kecamatan Gadingrejo dalam memasak daun katuk adalah dengan merebusnya hingga empuk, dan terbuka sehingga kandungan gizi yang terkandung berkurang. Sehingga diharapkan petugas kesehatan dapat memberikan penyuluhan tentang cara mengolah sayuran khususnya daun katuk dengan benar, sehingga diperoleh manfaat yang maksimal.

Daun kelor termasuk daun yang sulit untuk diperoleh, karena tidak dijual di pasar dan tidak ditanam secara khusus oleh masyarakat. Biasanya masyarakat memperolehnya dari kebun yang merupakan tanaman liar. Pohon dan daun Kelor sejak dulu banyak digunakan untuk lalaban (sayur mentah) maupun sayur untuk meningkatkan jumlah ASI ibu yang baru melahirkan. Cara penanaman daun kelor dapat diperbanyak baik dengan cara generatif maupun vegetatif, tidak memerlukan unsur hara dan air yang banyak. Tancapkan stek batang atau dahan. Cara lain tentu dengan cara menyemaikan biji Kelor dan memindahkan ke tanah saat anakan Kelor sudah cukup tinggi dan dianggap kuat.

Selain konsumsi sayur-sayuran, masyarakat Desa Wonosari Kecamatan Gadingrejo Kabupaten Pringsewu juga biasa mengkonsumsi jamu untuk meningkatkan produksi ASI salah satunya yaitu jamu kunyit dan asam jawa, jamu tersebut masyarakat peroleh dengan membuat sendiri atau dengan membeli langsung pada pedagang jamu gendong. Bahan yang perlu disipakan adalah kunir 3 ons, asam 2 ons, gula merah $3 \mathrm{~kg}$, gula pasir 3 ons, garam 1/4 sendok makan, dan air 5 liter. Dan cara membuatnya adalah direbus asam dan gula dengan air sampai mendidih sambil diaduk agar gula larut. Biarkan dingin dan saring. Ditumbuk bahan-bahan yang sesuai dengan komposisi racikan secara kasar menggunakan lumpang dan alu besi atau batu atau diiris tipis-tipis (kunyit). Diperas dan saring bahan yang sudah halus untuk diambil sarinya dan langsung dicampurkan dengan larutan gula asam sambil diaduk. Dimasukkan ke dalam botol yang bersih dan kering kemudian ditutup rapat.

Mayarakat di desa Wonosari tidak mengkonsumsi buah pepaya, jantng pisang, sari kacang hijau, meskipun buah dan tanaman ini dapat memerlancar produksi ASI. Masyarakat Wonosari justru mengkonsumsi beberapa tanaman di bawah ini seperti :

Sangrai jagung juga biasa dikonsumsi masyarakat untuk memperlancar produksi ASI. Namun, kalangan pakar kesehatan masih meragukan Marning (jagung) bisa menjadi makanan yang mampu melancarkan keluarnya ASI bagi ibu-ibu baru melahirkan. Berbeda dengan Marning, daun Katuk, 
justru sudah diteliti dan terbukti memiliki khasiat memperbanyak ASI.Makan marning setelah melahirkan, dianggap hanya sugesti bagi ibu-ibu baru yang menginginkan ASI-nya lancar.

Bayam mengandung zat besi, kalsium, dan asam folat. Zat besi penting untuk ibu yang mengalami anemia, ini juga membuat bayi kuat. Bayam mengandung bahan kimia nabati yang bisa membantu mencegah kanker payudara. Bayam bisa memasak bayam menjadi sayur sebagai lauk di siang hari atau mencampurnya dalam adonan tepung dan dijadikan roti.

Pada daun kacang panjang atau daun lemyung memiliki testur yang kasar dan keras sehingga sangat baik jika dikonsumsi pada daun yang masih muda saja. selain rasanya enak, daun lembayung juga memiliki kasiat dan kandungan gizi yang sangat baik untuk kesehatan tubuh. daun lembayung memiliki banyak kandungan gizi diantaranya adalah karbohidrat, vitamin A, protein, kalori, lemak, fosfor, kalsium, zat besi dan vitamin B serta zat BOD. Bagi ibu yang baru saja melahirkan sangat penting untuk mendapatkan produksi asi yang lancar sehingga asupan gizi dan nutrisi kepada bayi tidak tersendat dan membuat bayi akan tetap sehat. hal ini sangat penting karena pada saat bayi berusia dibawah 6 bulan tidak diperbolehkan mengkonsumsi makanan lain selain ASI karena bisa merusak sistem pencernaan bayi. Bagi ibu yang sedang menyusui ibu bisa mengkonsumsi daun lembayung baik dijadikan lalap, sayur, atau olahan makanan lainnya. daun lembayung juga tidak memiliki rasa atau aroma yang tajam sehingga tidak akan membuat ibu menyusui mual dan muntah.

Masyarakat di Desa Wonosari Kecamatan Gadingrejo Kabupaten Pringsewu biasa di konsumsi daun turi sebagai lalapan atau sayur bening. Daun turi diperoleh dihalaman atau perkarangan rumah, karena daun tersebut tidak dijual di pasar. Khasiat turi yang terdapat pada daun dan bunganya dapat memperlancar peningkatan produksi air susu Ibu (ASI), selain itu juga dapat digunakan sebagai sayur-sayuran, lalapan dan pecel. Masyarakat sebagian besar menggunakan daun turi yang masih muda dengan dikukus dan dilalap. Karena sifatnya yang tidak beracun, maka kedua jenis pohon turi dapat dimanfaatkan sebagai obat. Turi dapat mengobati penyakit diare, pusing, radang tenggorokan, demam, sakit kepala, hidung berlendir dan rematik (Arland, 2010). Pada daunnya juga digunakan sebagai obat batu ginjal dan antioksidan. Hampir semua bagian pohon turi dapat dimanfaatkan oleh manusia, bunganya banyak mengandung vitamin dan dapat dijadikan sayur pecel. Selain itu daun muda dan polong muda dapat juga dipakai sebagai sayur.

\section{SIMPULAN DAN SARAN}

Berdasarkan hasil penelitian dapat dikethaui bahwa untuk meningkatkan produksi ASI,responden mengkonsumsi:

1. Daun katuk yaitu sebanyak 52 responden $(43,4 \%)$,

2. Konsumsi daun kelor yaitu sebanyak 38 responden (31.6\%)

3. Kunyit dan asam jawa 9 responden $(7,5 \%)$

4. Daun turi 3 responden $(2,5 \%)$

5. Sangrai jagung 4 responden $(3,3 \%)$

6. Bayam 5 responden $(4.2 \%)$

7. Daun kacang panjang 9 responden $(7,5 \%)$

8. Buah pepaya, jantung pisang dan sari kacang hijau tidak dikonsumsi oleh responden untuk meningkatkan produksi ASI.

Saran-saran yang dapat diberikan:

1. Aplikatif

a. Bagi Ibu Menyusui 
Meningkatkan makanan bergizi dalam upaya memperbanyak produksi ASI seperti daun katuk, daun kelor, buah pepaya, jantung pisang dan lain-lain.

b. Bagi Masyarakat

Memanfaatkan kembali tumbuhan dan makanan disekitar yang dapat memperlancar ASI.

2. AKBID Medica Bakti Nusantara Pringsewu

Menambah literatur atau bahan bacaan di Perpustakaan mengenai galaktogogue.

3. DinasKesehatan

Perlunya penyebaran informasi mengenai manfaat ASI dan pentingnya mengkonsumsi makanan yang bergizi untuk ibu menyusui melalui seminar, penyuluhan, konseling dan media sosial.

4. Bagi Peneliti Selanjutnya

Melanjutkan penelitian dengan variabel yang berbeda sehingga diketahui bahan galaktogogue yang paling efektif dalam meningkatkan produksi ASI.

\section{DAFTAR PUSTAKA}

Budiarto Eko. 2010. Metodologi Penelitian Kedokteran. Jakarta : EGC

Badriah laelatul. 2013. Asuhan Kebidanan Postpartum. Bandung : refika aditama

Dewi Lia. 2013. Asuhan Kebidanan Pada Ibu Nifas. Jakarta : Salemba Medika

Dewi Triloka. 2014. Pengaruh Pemberian Sari Kacang Hijau Pada Ibu Nifas Dengan Kelancaran Produksi ASI. Jombang : Unifersitas Pesantren Tinggi Darul 'Ulum

Djajanti Dwi. 2013. Uji Efek Pelancar ASI Air Rebusan Daun Kelor Pada Mencit. Makassar : Farmasi Yamasi

HidayatAlimul. 2010. MetodePenelitianKebidanan DanTeknikAnalisis Data. Jakarta :SalembaMedika.

Hidayati Sri. 2016. Efektifitas Minum Jamu (Ramuan Daun Katuk, Kunyit, Lempuyangan, Asam Jawa) Terhadap Produksi ASI Pada Ibu Nifas. Semarang : Poltekkes Kemenkes

Lilis wijayanti. 2014. Pengaruh Pijat Oksitosin Terhadap Produksi ASI Pada Ibu Postpartum. Yoyakarta : STIKes 'asiyiyah

Lucie Widowati. 2011. Toksisitas Akut Dan Subkronis Ramuan Ekstrak Kelor Dan Klebet Sebagai Pelancar ASI Dan Penambah Gizi. Pusat Biomedis Dan Teknologi Dasar Kesehatan

Merlyna Suryaningsih. 2009. Gambaran Produksi Asi Antara Ibu Menyusui Yang Mengkonsumsi Daun Katuk Dengan Yang Tidak Mengkonsumsi Daun Katuk. Madura : STIKes Ngudiya Husada.

Notoatmodjo Soekidjo. 2012.Metodologi Penelitan Kesehatan. Jakarta : Rineka Cipta.

Sugiyono. 2013. Cara Mudah Menyusun : Skripsi, Tesis Dan Disertasi. Bandung : ALFABETA

Suksesty, c. Pengaruh Jus Campuran Kacang Hijau Terhadap Peningkatan Hormon Prolaktin Dan Berat Badan Bayi. Jurnal Ilmiah Bidan. 2, 3 (dec. 2017), 32-40. 
Susilo.2016. PanduanAsuhanNifasdan Evidence Based Practice. Yogyakarta: Deepublish.

Suprihatin, Dewi Siti. 2018. Perbedaan produksi ASI dalam pemberian olahan buah pepaya pada ibu postpartum di PMB Maria Kota Bandar Lampung tahun 2018. Jurnal Ilmiah Kesehatan STIKes Mitra RIA Husada: Vol VII no 02 ISSN 2252-9675

Tara, Aulianova, dkk. Efektivitas Ekstraksi Alkaloid dan Sterol Daun Katuk (Sauropus androgynus) terhadap Produksi ASI Vol 8, No 1 (2019): Medical Journal Of Lampung University ISSN 2337-3776

Puspitasari Indrawati. 2011. Gambaran Faktor-Fakor Yang Mempengaruhi Pemberian Susu Formula Pada Ibu Yang Mempunyai Bayi Usia 0-6 Bulan Di Bidan Praktik Swasta HJ. Renik Suprapti Kelurahan Banar Soka. Purwokerto: STIKes Harapan Bangsa.

Walyani Siwi. 2017. Asuhan Kebidanan Masas Nifas Dan Menyusui. Yogyakarta: PUSTAKABARUPRESS

Zakaria. Pengaruh Pemberian Ekstrak Daun Kelor terhadap Kuantitas Air Susu Ibu (ASI) JURNAL MKMI, Vol. 12 No. 3, September 2016 ISSN 0216-2482 